\title{
POTENTIAL USE OF ALKALINE-ACTIVATED INDONESIAN PUMICE POWDER AS LEAD ADSORBENT IN SOLUTION SYSTEM
}

\author{
Faridlotul Hasanah $^{1 *}$, Syaiful Anwar ${ }^{2}$, Arief Hartono ${ }^{2}$, and Untung Sudadi \\ ${ }^{1}$ Soil Science Study Program, Graduate School, IPB University, Babakan, Dramaga, Bogor, West Java \\ 16680, Indonesia \\ ${ }^{2}$ Department of Soil Science and Land Resources, Faculty of Agriculture, IPB University \\ Submitted: 2019-09-18 Accepted: 2019-12-09
}

\begin{abstract}
Pumice is a volcanic material that found abundant in Indonesia. Owing to its physicochemical characteristics it can be utilized as a low-cost natural adsorbent for cationic contaminants. This study aimed to assess the performances of adsorbents prepared from $\mathrm{NaOH}$-activated powder of Lombok and Kediri pumices for lead removal in solution systems based on their maximum adsorption capacity and removal efficiency parameters. The adsorption tests were done in batch experimentation using pumice powder of $74 \mu \mathrm{m}$ particle size activated with $0.5,1$, and $2 \mathrm{M} \mathrm{NaOH}$ and lead solutions with initial concentrations of $0-260 \mathrm{mg} \cdot \mathrm{L}^{-1}$. The most favorable $\mathrm{NaOH}$ activation concentration for both pumices was $0.5 \mathrm{M}$ which resulted from Lombok pumice prepared-adsorbent with $\mathrm{Pb}$ maximum adsorption capacity based on linearized conventional and rearranged Langmuir isothermal adsorption models of 236.4 and $186.3 \mathrm{mg} \cdot \mathrm{g}^{-1}$, while those of Kediri pumice were of 218.4 and 210.8 $\mathrm{mg} \cdot \mathrm{g}^{-1}$, respectively. The removal efficiency of both adsorbents were $>80 \%$ at the initial $\mathrm{Pb}$ concentration of $<100 \mathrm{mg} \cdot \mathrm{L}^{-1}$ and around $50-80 \%$ at $100-260 \mathrm{mg} \cdot \mathrm{L}^{-1}$. Both pumices are therefore considered potential to be utilized as an adsorbent for cationic contaminants in solution systems with reliable performances.
\end{abstract}

Keywords: Kediri pumice, Langmuir adsorption model, Lombok pumice, Natural adsorbent

How to Cite: Hasanah, F., Anwar, S., Hartono, A., and Sudadi, U. (2019). Potential Use of AlkalineActivated Indonesian Pumice Powder as Lead Adsorbent in Solution System. Sains Tanah Journal of Soil Science and Agroclimatology, 16(2): 203-215 (doi: 10.20961/stjssa.v16i2.34621)

Permalink/DOI: http://dx.doi.org/10.20961/stjssa.v16i2.34621

\section{INTRODUCTION}

Lead is one of the highly toxic heavy metal contaminants in the environment. Its contamination to the food chains can injure the fetal brain, kidneys, circulatory, and nervous systems, especially for children (Abas, Ismail, Kamal, \& Izhar, 2013). Blacksmith Institute included lead as the top six

\footnotetext{
* Corresponding Author :

Email: faridlotulhasanah@gmail.com
}

environmental toxic threats (Pure Earth \& Green Cross Switzerland, 2015). The sources of lead exposure to the environment include metal plating and finishing operation, wastes of battery industries, pigments and paints, factory chimneys, smelting of mine ores, fertilizers, and pesticides (Jaishankar, Tseten, Anbalagan, Mathew, \& Beeregowda, 2014; UNEP, 2018). According to the DALY's ranking for the worst polluting industries, based on contribution to the global burden disease, ULAB (used lead-acid battery) and lead 
smelting were positioned respectively as the first and third of the list (Mills-knapp et al., 2012; Pure Earth \& Green Cross Switzerland, 2016).

Environmental contaminations of $\mathrm{Pb}$ in Indonesia, among others, were reported by Paundanan, Riani, \& Anwar (2015); Riza, Bambang, \& Kismartini (2016); and Tjahjono \& Suwarno (2018). Waters of Kartini Beach, Central Java contained $\mathrm{Pb}$ of 0.009 mg. $\mathrm{L}^{-1}$ (Riza et al., 2016), while that of Palu Bay, Central Sulawesi was of 0.013-0.0392 mg. $\mathrm{L}^{-1}$ (Paundanan et al., 2015), and that of the river of Demak Estuary, Central Java ranged from 0.6037 to $0.6647 \mathrm{mg} . \mathrm{L}^{-1}$ (Tjahjono \& Suwarno, 2018), all were surpassing the water quality standard set in the Environment Minister Decree, Government of Indonesia No 51 year 2004 (i.e. $0.008 \mathrm{mg} . \mathrm{L}^{-1}$ ).

Treatment technologies to overcome heavy metal contamination in the environment have been widely developed, including precipitation, coagulation-flocculation, sedimentation, floatation, filtration, membrane processes, electrochemical techniques, biological processes, adsorption, and ion exchange, with varying levels of success. Adsorption is one of the most efficient strategies for the removal of various contaminants from aqueous solutions owing to a simple design, convenience, low cost, high efficiency, and wide adaptability (Foo \& Hameed, 2010; Zhang et al., 2019). For a long term treatment of heavy metal removal, the adsorption process is considered as the most effective and economical approach (Abas et al., 2013).

The adsorption capacity of an adsorbent can be improved by applying two fundamental approaches, i.e. preparation of new adsorbent with excellent performance for contamination control and optimization of the adsorption conditions (Zhang et al., 2019). Çifçi \& Meriç (2016) reported that pumice was a very attractive adsorbent of chromium (VI) from its maximum adsorption capacity that was higher than bentonite, clinoptilolite, and charcoal, and cost evaluation that was about 100 times cheaper than chitin, chitosan, and activated carbon.

This study is attempting to obtain adsorbents with higher lead adsorption capacity and removal efficiency as compared to several other adsorptive materials, including pumice, from other countries. The results of this study are expected to be beneficial for improving the utilization of Indonesian pumices, owing to their specific physicochemical characteristics and abundant reserves, as an excellent natural adsorbent for the removal of lead and other cationic contaminants from waters and wastewaters. This study aimed to assess the performances of adsorbent prepared from $\mathrm{NaOH}$-activated powder of two Indonesian pumices for lead removal in solution system based on the maximum adsorption capacity and removal efficiency parameters by applying the conventional and rearranged linearized Langmuir isothermal adsorption models.

\section{MATERIAL AND METHODS}

This research was conducted from November 2018 to June 2019. The pumice raw materials were obtained from the eruption's area of Mt. Rinjani and of Mt. Kelud at respectively Geres village, Labuhan Haji subdistrict, East Lombok district, West Nusa Tenggara province, and Wonorejo Trisulo village, Plosoklaten sub-district, Kediri district, East Java province. The experiments were carried out at the Laboratory of Soil Chemistry and Fertility Division, Faculty of Agriculture, IPB University. 


\section{Preparation and activation of pumice powder as adsorbent}

The materials were first ground and washed with running tap water to remove any impurities and rinsed with distilled water. Then, they were treated with $0.1 \mathrm{M} \mathrm{HCl}$ to dissolve acid-soluble impurities for further purification (Jonasi, Matina, \& Guyo, 2017). After $24 \mathrm{~h}$ acid treatment, the materials were washed again with distilled water to remove excess acid until the $\mathrm{pH}$ of the washing water was equal to that of distilled water. The washed materials were oven-dried at $60^{\circ} \mathrm{C}$ for $24 \mathrm{~h}$ to evaporate the remaining water. The dried materials were then milled and sieved to obtain pumice powder with the particle size of 200 mesh $(74 \mu \mathrm{m})$.

Chemical modification of the pumice powder to prepare and improve its adsorption capacity as a cationic adsorbent was done by alkaline treatment in which $4 \times 5$ g pumice powder were dissolved each in $50 \mathrm{~mL}$ of 0 (control), 0.5, 1, and $2 \mathrm{M} \mathrm{NaOH}$ and agitated using end-to-end shaker at $175 \mathrm{rpm}$ for $24 \mathrm{~h}$ at room temperature. The activated pumice powder was subsequently washed several times with distilled water to remove excess $\mathrm{NaOH}$ until $\mathrm{pH}$ of the washing water was equal to that of distilled water, and oven-dried at $105^{\circ} \mathrm{C}$ for $24 \mathrm{~h}$ to obtain solids for the batch experiment.

\section{Adsorption test}

The lead adsorption tests were carried out in batch experiments at $30^{\circ} \mathrm{C}$ by adding 14 $x 0.12 \mathrm{~g}$ of each adsorbents (activated-pumice powder, i.e. L0, L0.5, L1, L2, K0, K0.5, K1, and $\mathrm{K} 2$, where $\mathrm{L}$ designated for Lombok pumice; $\mathrm{K}$ for Kediri pumice; 0, 0.5, 1, and 2 for $\mathrm{NaOH}$ activation concentrations of 0 (natural pumice), $0.5,1$, and $2 M$, respectively) to polyethylene bottles containing lead solutions prepared from $\mathrm{Pb}\left(\mathrm{NO}_{3}\right)_{2}, 10 \mathrm{~mL} 0.01 \mathrm{M} \mathrm{CaCl}_{2}$ as background electrolyte, and distilled water up to a final volume of $100 \mathrm{~mL}$ to get solutions with initial $\mathrm{Pb}$ concentrations ranging from 0 to $260 \mathrm{mg} \cdot \mathrm{L}^{-1}(0,5,10,15,20,30,40,50,60$, $100,140,180,220$, and $\left.260 \mathrm{mg} \cdot \mathrm{L}^{-1}\right)$. The solutions were then agitated using end-to-end shaker at $150 \mathrm{rpm}$ for $100 \mathrm{~min}$ to ensure that maximum adsorption at equilibrium state was achieved (Jonasi et al., 2017). The solutions were filtered and their $\mathrm{pH}$ and $\mathrm{Pb}$ concentrations were then respectively determined by using $\mathrm{pH}$-meter and atomic absorption spectrophotometer (AAS). The working $\mathrm{pH}$ of the initial solution at equilibrium for $\mathrm{Pb}$ adsorption process on adsorbents prepared from Lombok pumice activated with $0,0.5,1$, and $2 \mathrm{M} \mathrm{NaOH}$ were $6.5,6.62,6.61$, and 6.54, while those from Kediri pumice were 6.17, 6.49, 6.38, and 6.2, respectively.

\section{Data analysis}

The maximum $\mathrm{Pb}$ adsorption capacity was calculated by using the linearized Langmuir isothermal adsorption model (Equation 1).

$\frac{\mathrm{C}}{\mathrm{x} / \mathrm{m}}=\frac{1}{\mathrm{~b}} \mathrm{C}+\frac{1}{\mathrm{~kb}}$

where $C=\mathrm{Pb}$ concentration at equilibrium (mg. $\left.\mathrm{L}^{-1}\right), x / m=$ amount of $\mathrm{Pb}$ adsorbed per unit mass of the adsorbent (mg.g $\left.{ }^{-1}\right), b=$ maximum amount of adsorbate $\left(\mathrm{Pb}^{2+}\right)$ that can be adsorbed as a complete monolayer by the adsorbent $\left(\mathrm{mg} \cdot \mathrm{g}^{-1}\right)$, and $k=$ adsorptiondesorption bonding energy for the adsorbate (Bohn, McNeal, \& O'Connor, 2001; Silva-yumi, Escudey, Gacitua, \& Pizarro, 2018). The Pb removal efficiency was determined using Equation 2.

Removal efficiency $(\%)=\left(\frac{\left(\mathrm{C}_{0}-\mathrm{C}_{\mathrm{t}}\right)}{\mathrm{C}_{\mathrm{p}}}\right) \times 100$

where $C_{o}=$ initial $\mathrm{Pb}$ concentration $\left(\mathrm{mg} \cdot \mathrm{L}^{-1}\right.$ ) and $C_{t}=\mathrm{Pb}$ concentration at equilibrium (mg. $\mathrm{L}^{-1}$ ) (Ponce-Lira et al., 2017). 


\section{RESULTS}

Lead adsorption isotherm shape and curvature

The adsorption reaction behavior can be interpreted by (1) identification of the adsorption isotherms shape and curvature, and (2) statistical modeling. The shape and curvature of lead adsorption isotherm (Figure 1) of the Lombok and Kediri adsorbents prepared from each respective alkalineactivated pumice powder by using the socalled conventional Langmuir model (Shukla, Matsue, Henmi, \& Johan, 2011) resembled Lshape curves that indicate the solid adsorbent have a high affinity for the solute (Tan, 2011). The Langmuir isotherm curve can also be described mathematically, known as the rearranged Langmuir model, by applying the statistical modeling method (Essington, 2004; Sposito, 2008).

\section{Lead maximum adsorption capacity based on conventional Langmuir model}

Lead adsorption isotherm plots of the tested Lombok and Kediri adsorbents prepared from each respective alkalineactivated pumice powder using the conventional linearized Langmuir model (Figure 2) show multiple-sites adsorption (two-sites) with different slopes and intercepts representing the maximum adsorption capacity and related binding strength, respectively. The two-sites Langmuir adsorption isotherm was linearized and rewritten from Equation 1 into Equation 3.

$\frac{x}{m}=\frac{b_{1} k_{1} C}{1+k_{1} C}+\frac{b_{2} k_{2} C}{1+k_{2} C}$

where $b_{1}$ and $k_{1}$ represent respectively the maximum adsorption capacity and binding strength of the first adsorption site, while $b_{2}$ and $k_{2}$ are of the second site. The value of $b$ and $k$ calculated respectively as $b_{1}+b_{2}$ and $k_{1}$ $+k_{2}$ (Essington, 2004; Sposito, 2008), are the maximum adsorption capacity and binding strength of the tested adsorbents for $\mathrm{Pb}$.

In summary, Figure 2 shows that for both Lombok and Kediri adsorbents, the curve slopes of the first adsorption site $\left(\mathrm{y}_{1}\right)$ are higher than the second one $\left(y_{2}\right)$; while the minimum slopes of both sites were obtained from $0.5 \mathrm{M} \mathrm{NaOH}$ activation. The opposite results were obtained for the intercepts. The maximum adsorption capacity and binding strength obtained from the two-sites conventional linearized Langmuir model are shown in Table 1.

\section{Lead maximum adsorption capacity based on the rearranged Langmuir model}

Rearranged linearized Langmuir adsorption model as explained by Essington (2004) and Sposito (2008) that uses $x / m / C$ as the $y$-axis and $x / m$ as the $x$-axis can be derived from Equation 4 and Equation 5.

$y_{1}=\left(\frac{\alpha_{1}}{\alpha_{0}}\right) x+\alpha_{0}$ and $y_{2}=\left(\frac{\beta_{0}}{\beta_{1}}\right) x+\left(\frac{\beta_{0}^{2}}{\mid \beta_{1}}\right)$

where $a_{0}=b_{1} k_{1}+b_{2} k_{2} ; a_{1}=-\left(b_{1} k_{1}^{2}+b_{2} k_{2}^{2}\right)$

; $\beta_{0}=b_{1}+b_{2} ;$ and $\beta_{1}=-\frac{b_{1}}{k_{1}}-\frac{b_{2}}{k_{2}}$

The adsorption isotherm curves applying the rearranged linearized Langmuir model for the tested adsorbents are given in Figure 3. The lead adsorption parameters derived from fitting the two-sites Langmuir adsorption isotherm using the rearranged Langmuir model are shown in Table 2.

Even though there were differences in $b$ values acquired from using the conventional and rearranged Langmuir model, the trends remain the same in which the highest $b$ values of both adsorbents were obtained from $0.5 \mathrm{M}$ $\mathrm{NaOH}$ activation. However, the conventional Langmuir model resulted in higher $r$ values (coefficient of correlation) that indicate a closer relationship between variables representing the lead maximum adsorption capacity than those of the rearranged 
Langmuir model. Therefore, the usage of the conventional Langmuir model was more preferred than the rearranged Langmuir model. By using the preferred conventional Langmuir model, the $b$ value of Lombok adsorbent obtained from $0.5 \mathrm{M} \mathrm{NaOH}$ activation was higher than that of Kediri adsorbent. This finding disclosed that Lombok pumice is more promising than Kediri pumice to be utilized as a raw material of lead adsorbent in the solution system.

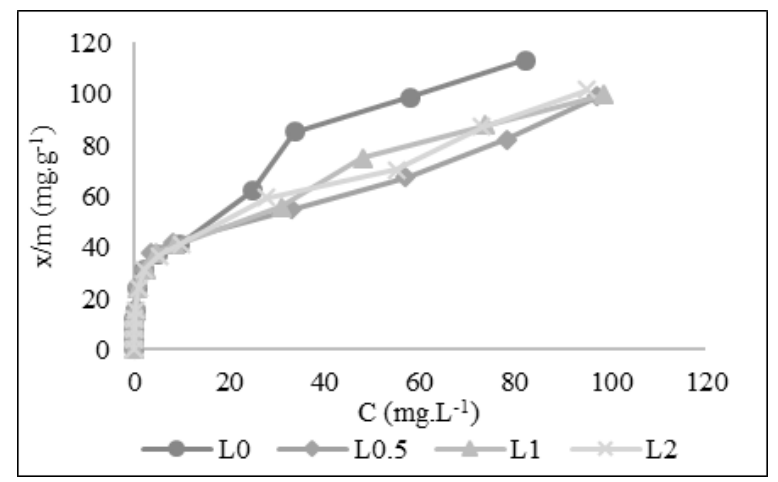

\section{Lead removal efficiency in the solution system}

The lead removal efficiency of the tested Lombok and Kediri adsorbents is shown in Figure 4. Overall, the removal efficiency of both adsorbents was more than $80 \%$ at $\mathrm{Pb}$ initial solution concentration of less than 100 mg. $\mathrm{L}^{-1}$ and around $50-80 \%$ at $100-260 \mathrm{mg} \cdot \mathrm{L}^{-1}$, in which that of Lombok adsorbent was higher than Kediri adsorbent.

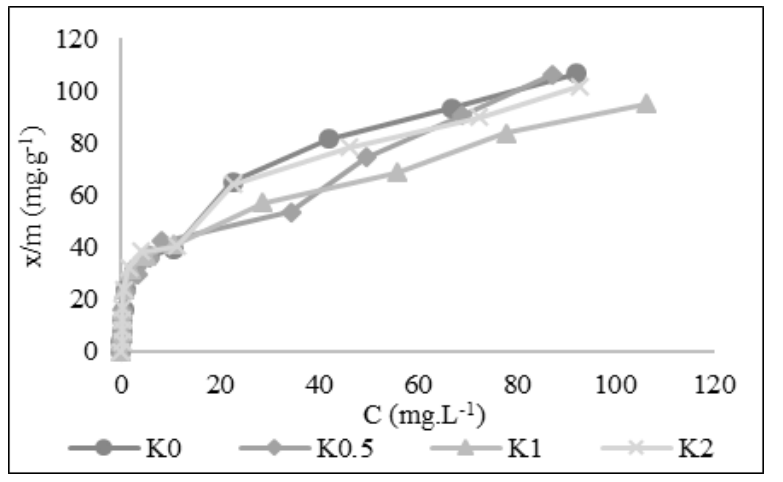

Figure 1. Lead adsorption isotherm curves of Lombok ( $L$, left) and Kediri (K, right) adsorbents prepared from each respective alkaline-activated pumice powder determined using the conventional linearized Langmuir model $(0.5,1$, and 2 denote $\mathrm{M} \mathrm{NaOH}$ concentration).
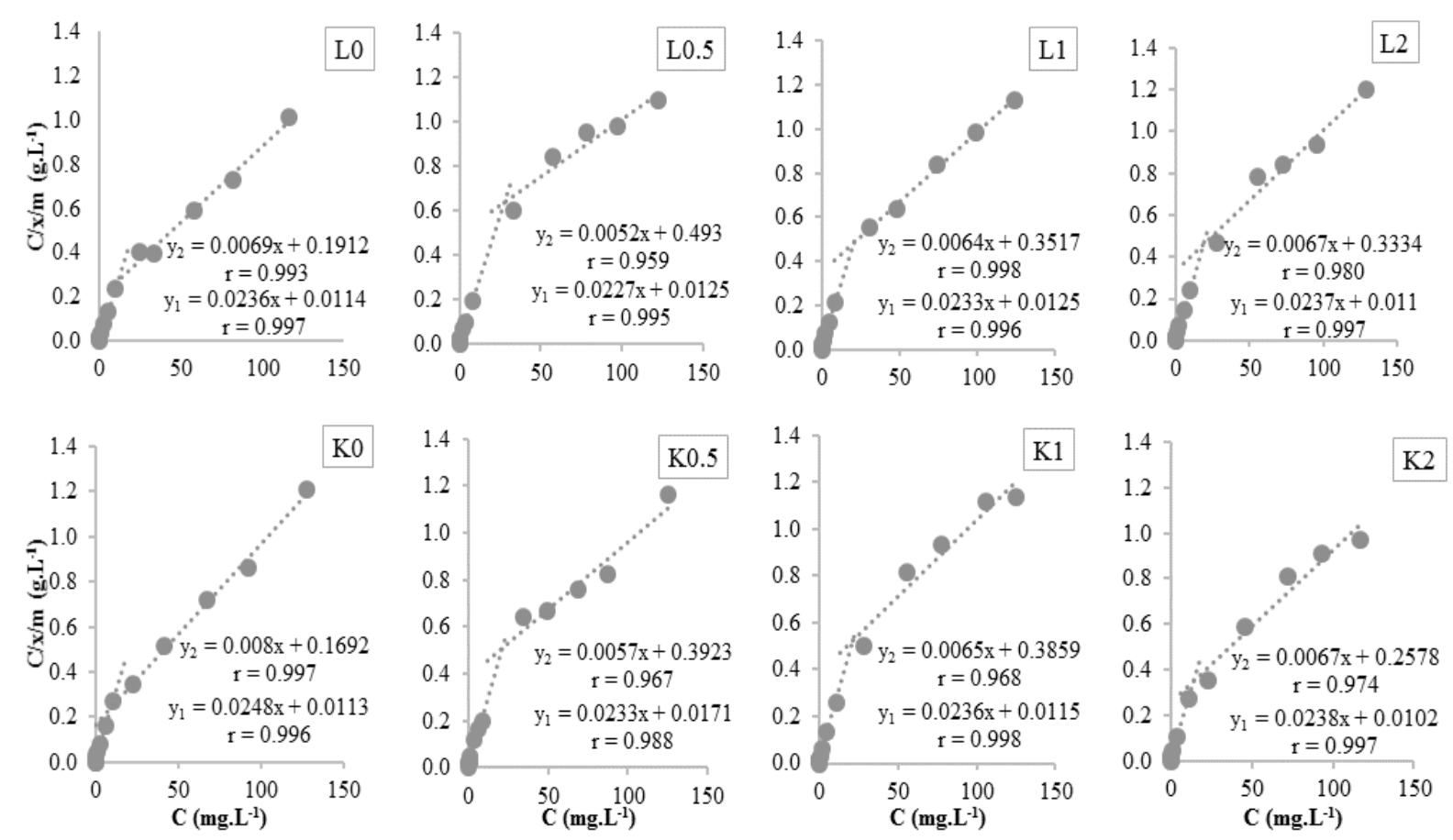

Figure 2. Lead adsorption isotherm plots of Lombok ( $\mathrm{L}$, top) and Kediri ( $\mathrm{K}$, bottom) adsorbents prepared from each respective alkaline-activated pumice powder obtain from the two-sites conventional linearized Langmuir model $(0.5,1$, and 2 denote $\mathrm{M} \mathrm{NaOH}$ concentration). 

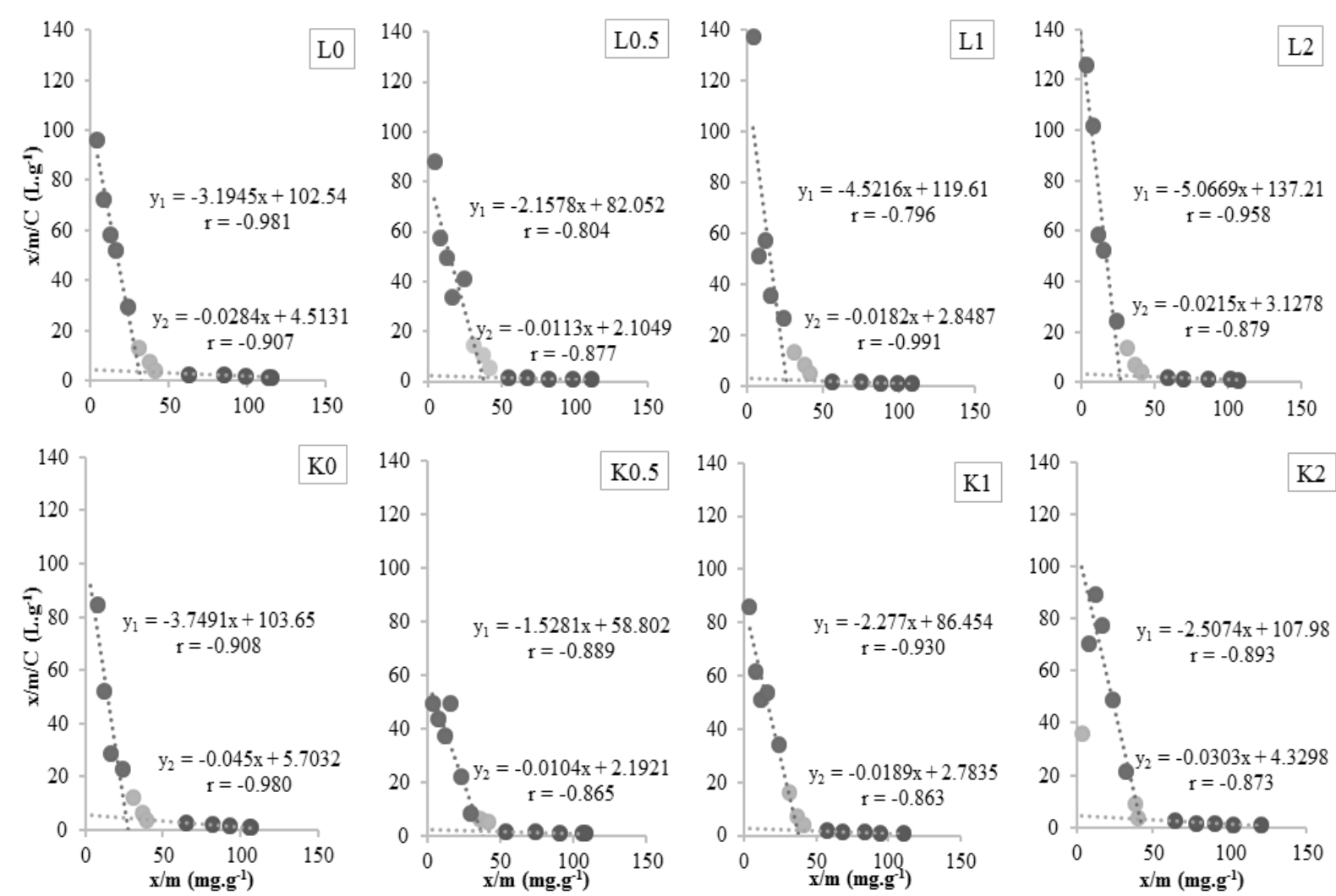

Figure 3. Lead adsorption isotherm plots of Lombok ( $\mathrm{L}$, top) and Kediri ( $\mathrm{K}$, bottom) adsorbents prepared from each respective alkaline-activated pumice powder obtain from the two-sites linearized rearranged Langmuir model $(0.5,1$, and 2 denote $\mathrm{M} \mathrm{NaOH}$ concentration).

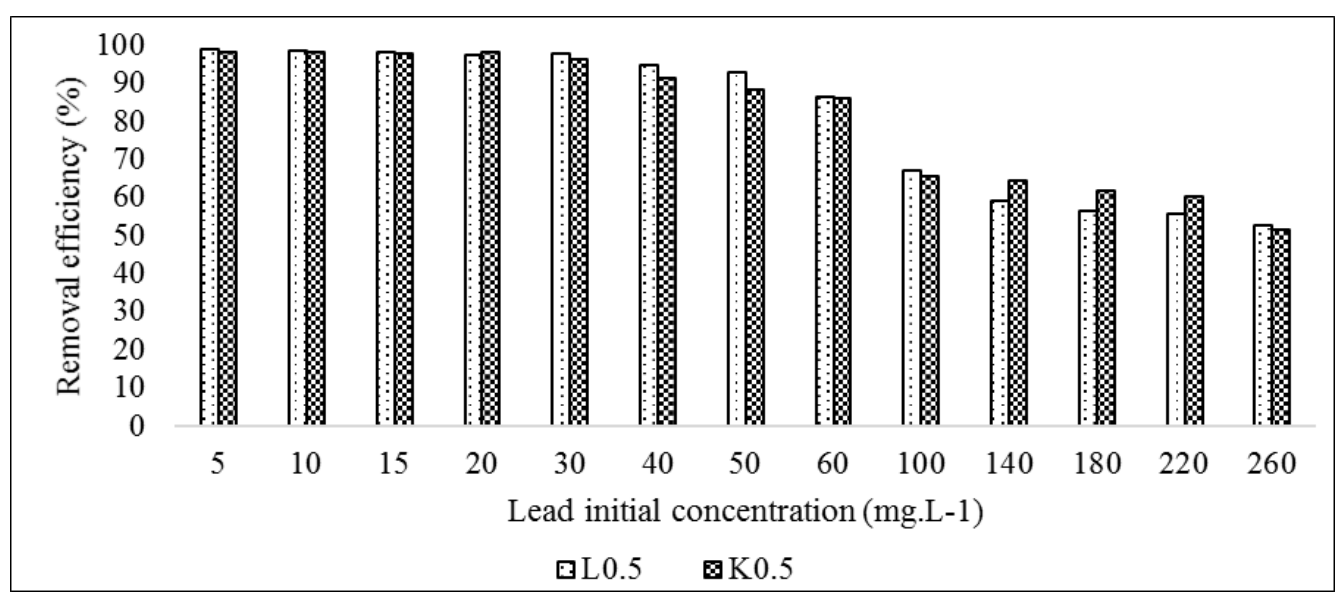

Figure 4. Lead removal efficiency Lombok (L, left) and Kediri (K, right) adsorbents prepared from each respective $0.5 \mathrm{M} \mathrm{NaOH}$-activated pumice powder at lead solution initial concentrations of 0 to $260 \mathrm{mg} \cdot \mathrm{L}^{-1}$.

\section{DISCUSSION}

Pumice is composed of XRD-amorphous silicate minerals with a porous structure (Ismail, El-Shafey, Amr, \& El-Maghraby, 2014; Sepehr, Amrane, Karimaian, Zarrabi, \& Ghaffari, 2014). FTIR spectra of natural pumice commonly indicates the stretching and bending of $\mathrm{Si}-\mathrm{O}-\mathrm{Si}$ from $\left(\mathrm{SiO}_{4}\right)^{2-}$ groups, stretching vibration of $-\mathrm{OH}$ groups and $\mathrm{H}_{2} \mathrm{O}$ molecules in the lattice, and vibration of $\mathrm{H}-\mathrm{O}-$ $\mathrm{H}$ bond of lattice water molecules (Sepehr et al., 2014, 2013). Its reactive surface ends with 
$-\mathrm{OH}$ groups and oxygen bridges which perform as adsorption spots (Çifçi \& Meriç, 2016).

In general, the values of $b_{1}$ obtained from applying the conventional, as well as the rearranged Langmuir, the model was lower than $b_{2}$, while the values of $k_{1}$ were higher than $k_{2}$ (Table 1 and Table 2). The lower $b$ and higher $k$ value of the first site as compared to the second site could be explained using the Stern model and triple-layer model (Zhang et al., 2019). Metal adsorption may have occurred on the 0-plane, $\beta$-plane or d-plane of the triple-layer model (Criscenti \& Sverjensky, 1999). Thus, it could be proposed that the higher $b$ value and the lower $k$ value of the second site than the first one were due to the further distance of the adsorbate to the adsorbent surface. The possible metal surface complexation in the framework of the triplelayer model is that metal cations may bind to deprotonated or neutral surface sites as bare or hydrated metal ions, metal hydroxide complexes, and metal electrolyte anion complexes. In this study, metal-electrolyte anion complexes (between $\mathrm{Pb}^{2+}$ and $\mathrm{Cl}^{-}$from $\mathrm{CaCl}_{2}$ ) might be formed but not until precipitation occurred. However, according to Speight (2005), the value of reaction quotient,
$\mathrm{Q}$, of $\mathrm{PbCl}_{2}$ (ranged from $2.3 \times 10^{-13}$ to $3.1 \times$ $\left.10^{-10}\right)$ is much lower than its corresponding $\mathrm{Ksp}$ value $\left(1.7 \times 10^{-5}\right)$, indicating that precipitation of $\mathrm{PbCl}_{2}$ can not occur. Besides, the equilibrium $\mathrm{pH}$ values of the solution systems with initial $\mathrm{Pb}$ concentration from 5 to $260 \mathrm{mg} . \mathrm{L}^{-1}$ in the present study were varied from 6.05-5.34 and 5.88-5.26 for the usage of adsorbents prepared from Lombok and Kediri pumice powder activated with $0.5 \mathrm{M} \mathrm{NaOH}$, respectively. According to Bradl (2004), $\mathrm{Pb}(\mathrm{OH})^{+}$is predominant in systems with $\mathrm{pH}$ between 6 and 10, while at $\mathrm{pH}$ above 9, the formation of $\mathrm{Pb}(\mathrm{OH})_{2}$ is important. It can be stated therefore that precipitation of $\mathrm{Pb}$ either as $\mathrm{PbCl}_{2}, \mathrm{~Pb}(\mathrm{OH})^{+}$or $\mathrm{Pb}(\mathrm{OH})_{2}$ were not occurring in the present study.

Comparison of the maximum adsorption capacity ( $b$ value) of the Lombok and Kediri adsorbent tested in the present study with those of several types of adsorbent reported in the literature, including pumice, is given in Table 3 . It shows that both the Lombok and Kediri adsorbents tested in the present study performed higher lead maximum adsorption capacity as compared to the other pumice-based adsorbent, except the pure nano-ball allophane from Japan.

Table 1. Lead maximum adsorption capacity ( $b$ value) and binding strength ( $k$ value) of adsorbents prepared from alkaline-activated Lombok and Kediri pumice powder obtained from the two-sites conventional linearized Langmuir model

\begin{tabular}{|c|c|c|c|c|c|c|c|}
\hline $\begin{array}{l}\text { Adsorbents } \\
\text { prepared from }\end{array}$ & $\begin{array}{r}\text { Activated } \\
\text { with }\end{array}$ & $b_{1}$ & $b_{2}$ & $B$ & $\mathbf{k}_{1}$ & $k_{2}$ & $k$ \\
\hline \multirow{5}{*}{$\begin{array}{l}\text { Lombok } \\
\text { pumice powder }\end{array}$} & & \multicolumn{3}{|c|}{$\left(\mathrm{mg} \cdot \mathrm{g}^{-1}\right)$} & \multicolumn{3}{|c|}{$\left(\right.$ L.g $\left.^{-1}\right)$} \\
\hline & $0 \mathrm{M} \mathrm{NaOH}$ & 42.37 & 144.93 & 187.30 & 2.07 & 0.04 & 2.11 \\
\hline & $0.5 \mathrm{M} \mathrm{NaOH}$ & 44.05 & 192.31 & 236.36 & 1.82 & 0.01 & 1.83 \\
\hline & $1 \mathrm{M} \mathrm{NaOH}$ & 42.92 & 156.25 & 199.17 & 1.86 & 0.02 & 1.88 \\
\hline & $2 \mathrm{M} \mathrm{NaOH}$ & 42.19 & 149.25 & 191.44 & 2.16 & 0.02 & 2.18 \\
\hline \multirow{4}{*}{$\begin{array}{l}\text { Kediri } \\
\text { pumice powder }\end{array}$} & $0 \mathrm{M} \mathrm{NaOH}$ & 40.32 & 125.00 & 165.32 & 2.20 & 0.05 & 2.25 \\
\hline & $0.5 \mathrm{M} \mathrm{NaOH}$ & 42.92 & 175.44 & 218.36 & 1.36 & 0.02 & 1.38 \\
\hline & $1 \mathrm{M} \mathrm{NaOH}$ & 42.37 & 153.85 & 196.22 & 2.05 & 0.02 & 2.07 \\
\hline & $2 \mathrm{M} \mathrm{NaOH}$ & 42.02 & 149.25 & 191.27 & 2.33 & 0.03 & 2.36 \\
\hline
\end{tabular}


Table 2. Lead maximum adsorption capacity ( $b$ value) and binding strength ( $k$ value) of the adsorbents prepared from alkaline-activated Lombok and Kediri pumice powder obtained from the two-sites rearranged linearized Langmuir model

\begin{tabular}{|c|c|c|c|c|c|c|c|}
\hline $\begin{array}{l}\text { Adsorbents } \\
\text { prepared from }\end{array}$ & $\begin{array}{r}\text { Activated } \\
\text { with }\end{array}$ & $b_{1}$ & $b_{2}$ & $\boldsymbol{b}$ & $\mathbf{k}_{1}$ & $k_{2}$ & $k$ \\
\hline \multirow{5}{*}{$\begin{array}{l}\text { Lombok } \\
\text { pumice powder }\end{array}$} & & \multicolumn{3}{|c|}{$\left(\mathrm{mg} \cdot \mathrm{g}^{-1}\right)$} & \multicolumn{3}{|c|}{$\left(L^{\prime} g^{-1}\right)$} \\
\hline & $0 \mathrm{M} \mathrm{NaOH}$ & 30.28 & 128.64 & 158.92 & 3.29 & 0.02 & 3.31 \\
\hline & $0.5 \mathrm{M} \mathrm{NaOH}$ & 36.78 & 149.49 & 186.27 & 2.19 & 0.01 & 2.20 \\
\hline & $1 \mathrm{M} \mathrm{NaOH}$ & 25.58 & 130.94 & 156.52 & 4.60 & 0.02 & 4.62 \\
\hline & $2 \mathrm{M} \mathrm{NaOH}$ & 26.26 & 119.22 & 145.48 & 5.15 & 0.02 & 5.17 \\
\hline \multirow{4}{*}{$\begin{array}{l}\text { Kediri } \\
\text { pumice powder }\end{array}$} & $0 \mathrm{M} \mathrm{NaOH}$ & 25.75 & 100.99 & 126.74 & 3.88 & 0.04 & 3.92 \\
\hline & $0.5 \mathrm{M} \mathrm{NaOH}$ & 36.55 & 174.23 & 210.78 & 1.57 & 0.01 & 1.58 \\
\hline & $1 \mathrm{M} \mathrm{NaOH}$ & 36.60 & 110.67 & 147.28 & 2.32 & 0.01 & 2.33 \\
\hline & $2 \mathrm{M} \mathrm{NaOH}$ & 41.34 & 101.56 & 142.90 & 2.56 & 0.02 & 2.58 \\
\hline
\end{tabular}

Table 3. Comparison of $\mathrm{Pb}^{2+}$ maximum adsorption capacity of several types of adsorbents obtained from applying the conventional linearized Langmuir model

\begin{tabular}{lcl}
\hline Type of adsorbent & $\begin{array}{c}\text { Maximum adsorption } \\
\text { capacity }\left(\mathbf{m g}^{-\mathbf{1}}\right)\end{array}$ & Reference \\
\hline Allophane, Kumamoto prefecture, Japan & 370.40 & Elsheikh et al. (2018) \\
Alkaline-activated pumice, Kediri, Indonesia & 236.36 & Present study \\
Alkaline-activated pumice, Lombok, Indonesia & 218.36 & Present study \\
Bentonite, Anarak, Iran & 71.00 & Hamidpour et al. (2014) \\
Zeolite, Firouzkoh, Iran & 75.00 & Hamidpour et al. (2014) \\
KCC-1 (fibrous silica nanosphere) & 41.61 & Hasan and Setiabudi \\
Alkaline-modified pumice & 28.09 & (2018) Jonasi et al. (2017) \\
Natural Gisenyi volcanic rock, Rwanda & 9.52 & Sekomo et al. (2012) \\
Natural pumice, Turkey & 7.46 & Şahan and Öztürk (2014) \\
Silica-based adsorbent & 5.34 & Liu and Wang (2013) \\
Natural pumice, Kurdistan, Iran & 5.31 & Moradi et al. (2015) \\
\hline
\end{tabular}

The higher maximum $\mathrm{Pb}$ adsorption capacity of the Lombok adsorbent than that of Kediri adsorbent can be attributed to their petrology and geochemistry. Based on the volcanic rock petrology and geochemistry data, from the Western Sunda arc to the Eastern Lesser Sunda island, there was a decrease in $\mathrm{SiO}_{2}$ content $\left(\% \mathrm{w}_{\mathrm{t}}\right)$, followed by an increase in $\mathrm{K}_{2} \mathrm{O}, \mathrm{Na}_{2} \mathrm{O}$, and $\mathrm{MgO}$ content $\left(\% \mathrm{w}_{\mathrm{t}}\right)$ (Dempsey, 2013; Foden, 1979). As reported by Whitford, Nicholls, \& Taylor (1979), the $\mathrm{K}_{2} \mathrm{O}$ content increase is abundant across the Sunda arc, which indicates the existence of spatial variations in the observed geochemistry, and the transition from calc-alkaline to alkaline lavas (Edwards et al., 1994). The same results were reported by Wheller, Varne, Foden, \& Abbott (1987) that from West to East of the West Java, Bali, and Flores arc sectors, each comprises volcanoes which become progressively more K-rich Eastwards. As reported by Aristantha, Hendrawan, \& Asmaranto (2017), the chemical composition in percentage of Kediri pumice, determined using AAS, was $81.27 \mathrm{SiO}_{2}, 13.69 \mathrm{Al}_{2} \mathrm{O}_{3}, 3.25$ $\mathrm{Fe}_{2} \mathrm{O}_{3}, 0.26 \mathrm{Fe}_{2} \mathrm{O}_{2}, 0.59 \mathrm{Na}_{2} \mathrm{O}, 0.135 \mathrm{~K}_{2} \mathrm{O}$, and $0.39 \mathrm{MgO}$, whereas that of Lombok pumice, determined using XRF, was $58.3 \mathrm{SiO}_{2}, 12.4$ 
$\mathrm{Fe}_{2} \mathrm{O}_{3}, 12 \mathrm{Al}_{2} \mathrm{O}_{3}, 7.73 \mathrm{~K}_{2} \mathrm{O}, 6.75 \mathrm{CaO}, 1.45 \mathrm{TiO}_{2}$, and $0.42 \mathrm{MnO}$ (Kusumaningtyas et al., 2017). Increasing content of base oxides such as $\mathrm{K}_{2} \mathrm{O}$ caused the development of basaltic characteristic of the volcanic rock which resulted in enhancement of cation exchange sites that explains why adsorbent prepared from Lombok pumice powder has a higher lead adsorption capacity than that of Kediri pumice.

Decreasing lead adsorption capacity with increasing $\mathrm{NaOH}$ concentration activation can be explained by the dissolution mechanism of the pumice constituent minerals. As a volcanic material, pumice is commonly composed of allophane and imogolite. These minerals are arranged by short-ranged and poorly ordered aluminum silicates. The reaction mechanism for the dissolution of allophane with alkaline solution occurred in two steps. The first step is deprotonation of alkali ion adsorbed on the silanol group, followed by a nucleophilic attack of Si by hydroxyl ion (Abidin, Matsue, \& Henmi, 2004). Si-OH groups are dissociated to form cation exchange retention site, $\mathrm{Si}_{-} \mathrm{O}^{-}$, then cation $\mathrm{Na}^{+}$is adsorbed. The next step is an attack by $\mathrm{OH}^{-}$toward the pore $\mathrm{Si}$ atom whose positive charge has been increased by $\mathrm{Na}^{+}$exchange (Abidin, Matsue, \& Henmi, 2005). Furthermore, Wang et al. (2018) stated that at $\mathrm{pH}<11.0$, preferential dissolution of the polymerized silicates that are mainly occurred, but the dissolved $\mathrm{Si}$ and $\mathrm{Al}$ are small. At $\mathrm{pH}>11.0$, desilication and dealumination are increasing, resulting in the dissolution of the imogolite local structure (ImoLS) along the edges of the defect pores. In the case of $\mathrm{pH}=$ 12.5, more of the ImoLS is dissolved, most of the defect pores are enlarged, some of the secondary pores are disrupted, and some hollow spherules may have collapsed. In this study, increasing $\mathrm{NaOH}$ concentrations exceeding $0.5 \mathrm{M}$ during the activation process may develop deprotonation of the $\mathrm{Si}$ or $\mathrm{Al}$ terminal sites that control the dissolution of the aluminosilicate minerals.

The higher $k$ value of the first site as compared to the second site (Table 1 and Table 2) represents that at similar adsorption rate, the desorption rate from the second site is higher and shows that the binding energy of the first site is higher than second site (Sposito, 2008). The high affinity between adsorbent and adsorbate occurs at the beginning of adsorption process, i.e. when the adsorbent surface covered by the adsorbate is still low and the affinity will decrease with increasing surface closure of the adsorbent by the adsorbate (Essington, 2004; Fonseca, Figueiredo, Rodrigues, Queiroz, \& Tavares, 2011; Giles, MacEwan, Nakhwa, \& Smith, 1960). The $k$ value, from a practical aspect, can be used as a guide in the regeneration of adsorbent or adsorbate desorption. Desorption study using $0.1 \mathrm{M} \mathrm{HNO}_{3}$ of Gisenyi volcanic rock $\left(k=0.014 \mathrm{~L} . \mathrm{mg}^{-1}\right)$ yielded desorption percentage of approximately $85 \%$ (Sekomo, Rousseau, \& Lens, 2012), while that using $0.05-0.2 \mathrm{M} \mathrm{HCl}$ on $0.1 \mathrm{M} \mathrm{NaOH}$-modified

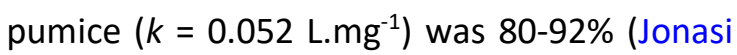
et al., 2017; Sekomo, Rousseau, \& Lens, 2012). Silva-yumi et al. (2018) disclosed that the higher value of $k$ resulting in the lower desorption percentage.

Lead removal efficiency of the adsorbents tested in the present study were in accordance with that reported by Şahan \& Öztürk (2014) that yielded a value of $88.49 \%$ at optimum conditions (adsorbent mass 10 g. $\mathrm{L}^{-1}$, initial $\mathrm{Pb}$ concentration $84.30 \mathrm{mg} \cdot \mathrm{L}^{-1}, \mathrm{pH}$ 5.75 , and temperature $41.1^{\circ} \mathrm{C}$ ), but higher than those reported by Jonasi et al. (2017); Moradi, Kalantary, Khosravi, \& Sharafi (2015); and Sekomo et al. (2012). 


\section{CONCLUSION}

The lead maximum adsorption capacity of adsorbents prepared from Lombok and Kediri pumice powder at the most favorable $0.5 \mathrm{M} \mathrm{NaOH}$ activation based on the conventional Langmuir model were 236.4 and $218.4 \mathrm{mg} \cdot \mathrm{g}^{-1}$, while those based on the rearranged Langmuir model were 186.3 and $210.8 \mathrm{mg}^{-1} \mathrm{~g}^{-1}$, respectively. Both adsorbents yielded lead removal efficiency of $>80 \%$ at $\mathrm{Pb}$ initial concentration of $<100 \mathrm{mg} \cdot \mathrm{L}^{-1}$ and around $50-80 \%$ at $100-260 \mathrm{mg} \cdot \mathrm{L}^{-1}$. It is therefore considered that both pumices are potential to be utilized as raw materials for preparing new natural cationic adsorbent in a solution system with reliable performance.

\section{ACKNOWLEDGMENTS}

The research work was supported by the Soil Chemistry and Fertility Division, Department of Soil Science and Land Resource, Faculty of Agriculture, IPB University. The authors were very grateful to Irma Wardani and Irene Handayani for their help in laboratory work.

\section{REFERENCES}

Abas, S. N. A., Ismail, M. H. S., Kamal, M. L., \& Izhar, S. (2013). Adsorption rocess of heavy metals by low-cost adsorbent: A review. World Applied Science Journal, 28(11), 1518-1530. https://doi.org/10.5829/idosi.wasj.2013. 28.11.1874

Abidin, Z., Matsue, N., \& Henmi, T. (2004). Dissolution mechanism of nano-ball allophane with dilute alkali solution. Clay Science, 12(4), 213-222. https://doi.org/10.11362/jcssjclayscienc e1960.12.213

Abidin, Z., Matsue, N., \& Henmi, T. (2005). Molecular orbital analysis on the dissolution of nano-ball allophane under alkaline condition. Clay Science, 13(1), 16. https://doi.org/10.11362/jcssclayscience
1960.13.1

Aristantha, F., Hendrawan, A. P., \& Asmaranto, R. (2017). Identifikasi karakteristik fisik dan mineralogi material piroklastik hasil erupsi gunung kelud di sungai kali sambong desa pandansari kecamatan ngantang kabupaten malang sebagai alternatif material timbunan. Jurnal Mahasiswa Jurusan Teknik Pengairan, 1(1). Retrieved from http://pengairan.studentjournal.ub.ac.id /index.php/jmtp/article/view/24/23

Bohn, H. L., McNeal, B. L., \& O'Connor, G. A. (2001). Soil Chemistry (3rd ed.). Toronto: John Wiley \& Sons, Inc.

Bradl, H. B. (2004). Adsorption of heavy metal ions on soils and soils constituents. Journal of Colloid and Interface Science, 277, 1-18. https://doi.org/10.1016/j.jcis.2004.04.00 5

Çifçi, D. İ., \& Meriç, S. (2016). A review on pumice for water and wastewater treatment. Desalination and Water Treatment, 57(39), 18131-18143. https://doi.org/10.1080/19443994.2015. 1124348

Criscenti, L. J., \& Sverjensky, D. A. (1999). The role of electrolyte anions (ClO4-, NO3and $\mathrm{Cl}-$ ) in divalent metal (M2+) adsorption on oxide and hydroxide surface in salt solutions. American Journal of Science, 299(10), 828-899. https://doi.org/10.2475/ajs.299.10.828

Dempsey, S. R. (2013). Geochemistry of Volcanic Rocks from the Sunda Arc. Durham University.

Edwards, C. M. ., Menzies, M. A., Thirlwall, M. F., Morris, J. D., Leeman, W. P., \& Harmon, R. S. (1994). The transition to potassic alkaline volcanism in island arcs: The Ringgit-Beser Complex, East Java, Indonesia. Journal of Petrology, 35(6), 1557-1595. https://doi.org/10.1093/petrology/35.6. 1557

Elsheikh, M. A., Muchaonyerwa, P., Johan, E., Matsue, N., \& Henmi, T. (2018). Mutual adsorption of lead and phosphorus onto selected soil clay minerals. Advance in Chemical and Science, 8(2), 67-81. 
https://doi.org/10.4236/aces.2018.8200 5

Essington, M. E. (2004). Soil and Water Chemistry: An Integrative Approach. CRC Press LLC.

Foden, J. D. (1979). The petrology of some young volcanic rocks from Lombok and Sumbawa, Lesser Sunda Islands. University of Tasmania.

Fonseca, B., Figueiredo, H., Rodrigues, J., Queiroz, A., \& Tavares, T. (2011). Mobility of $\mathrm{Cr}, \mathrm{Pb}, \mathrm{Cd}, \mathrm{Cu}$, and $\mathrm{Zn}$ in a loamy sand soil: A comparative study. Geoderma, 164(3-4), 232-237. https://doi.org/10.1016/j.geoderma.201 1.06.016

Foo, K. Y., \& Hameed, B. H. (2010). Insights into the modeling of adsorption isotherm systems. Chemical Engineering Journal, 156, 2-10. https://doi.org/10.1016/j.cej.2009.09.01 3

Giles, C. H., MacEwan, T. H., Nakhwa, S. N., \& Smith, D. (1960). Studies in adsorption. Part XI. A system of classification of solution adsorption isotherms, and its use in diagnosis of adsorption mechanisms and in measurement of specific surface areas of solids. Journal of the Chemical Society, 3973-3993. https://doi.org/10.1039/JR9600003973

Hamidpour, M., Kalbasi, M., Majid, A., Sharia, Madari, H., \& Furrer, G. (2014). Sorption of lead on Iranian bentonite and zeolite: Kinetics and isotherms. Environmental Earth Science, 62(3), 559-568. https://doi.org/10.1007/s12665-0100547-x

Hasan, R., \& Setiabudi, H. (2018). Removal of $\mathrm{Pb}$ (II) from aqueous solution using KCC1: Optimization by response surface methodology (RSM). Journal of King Saud University-Science. https://doi.org/10.1016/j.jksus.2018.10. 005

Ismail, A. I. M., El-Shafey, O. ., Amr, M. H. A., \& El-Maghraby, M. . (2014). Pumice characteristics and their utilization on the synthesis of mesoporous minerals and on the removal of heavy metals. International Scholarly Research Notice,
9. https://doi.org/10.1155/2014/259379 Jaishankar, M., Tseten, T., Anbalagan, N., Mathew, B. B., \& Beeregowda, K. N. (2014). Toxicity, mechanism and health effects of some heavy metals. Interdisciplinary Toxicology, 7(2), 60-72. https://doi.org/10.2478/intox-2014-0009 Jonasi, V., Matina, K., \& Guyo, U. (2017). Removal of $\mathrm{Pb}$ (II) and $\mathrm{Cd}(\mathrm{II})$ from aqueous solution using alkaline-modified pumice stone powder (PSP): Equilibrium, kinetic and thermodynamic studies. Turkish Journal of Chemistry, 41, 748759. https://doi.org/10.3906/kim-170140

Kusumaningtyas, M. P., Regina, G. L. D., Ade, L. N. F., Haiyina, H. A., Nura, H. H., \& Darminto. (2017). Synthesis of zeolites from Lombok pumice as silica source for ion exchanger. In (pp. 244-247). In The 1st International Basic Science Conference: Towards the extended use of basic science for enhancing health, environment, energy, and biotechnology (pp. 244-247). Jember, Indonesia: University of Jember. Retrieved from https://jurnal.unej.ac.id/index.php/prosi ding/article/view/4232

Liu, J., \& Wang, X. (2013). Novel silica-based hybrid adsorbents: Lead (II) adsorption isotherms. The Scientific World Journal, 897159, 6. https://doi.org/10.1155/2013/897159

Mills-knapp, S., Traore, K., Ericson, B., Keith, J., Gysi, N., \& Caravanos, J. (2012). The World's Worst Pollution Problems: Assessing Health Risks at Hazardous Waste Sites.

Moradi, M., Kalantary, R. R., Khosravi, T., \& Sharafi, K. (2015). Equilibrium isotherms and kinetic studies of lead removal from aqueous solution by pumice powder. Technical Journal of Engineering and Applied Science, 5(1), 69-79.

Paundanan, M., Riani, E., \& Anwar, S. (2015). Heavy metals contamination mercury $(\mathrm{Hg})$ and lead $(\mathrm{Pb})$ in water, sediment, and torpedo scad fish (Megalaspis cordyla L) in Palu Bay, Central Sulawesi. Jurnal Pengelolaan Sumberdaya Alam Dan Lingkungan, 5(2), 161-168. 
https://doi.org/10.19081/jpsl.5.2.161

Ponce-Lira, B., Otazo-Sa'nchez, E., Reguera, E., Acevedo-Sandoval, O., Prieto-Garcia, F., \& Gonza'lez-Ramı́rez, C. (2017). Lead removal from aqueous solution by basaltic scoria: Adsorption equilibrium and kinetics. International Journal of Environmental Science Technology, 14(6), 1181-1196. https://doi.org/10.1007/s13762-0161234-6

Pure Earth, \& Green Cross Switzerland. (2015). World's worst pollution problems 2015: The new top six toxic threats priority list for remediation.

Pure Earth, \& Green Cross Switzerland. (2016). World's worst pollution problems 2016: The toxics beneath our feet.

Riza, F., Bambang, A. N., \& Kismartini. (2016). Water environment pollution of heavy metals $\mathrm{Pb}, \mathrm{Cd}$, and $\mathrm{Hg}$ in Jepara Kartini Beach Central Java, Indonesia. Research Journal of Marine Science, 4(1), 1-4.

Şahan, T., \& Öztürk, D. (2014). Investigation of $\mathrm{Pb}$ (II) adsorption onto pumice samples: Application of optimization method based on fractional factorial design and response surface methodology. Clean Technologies and Environmental Policy, 16(5), 819-831. https://doi.org/10.1007/s10098-0130673-8

Sekomo, C. B., Rousseau, D. P. L., \& Lens, P. N. L. (2012). Use of Gisenyi volcanic rock for adsorptive removal of $\mathrm{Cd}(\mathrm{II}), \mathrm{Cu}(\mathrm{II})$, $\mathrm{Pb}(\mathrm{II})$, and $\mathrm{Zn}(\mathrm{II})$ from wastewater. Water, Air and Soil Pollution, 223(2), 533-547.

https://doi.org/10.1007/s11270-0110880-z

Sepehr, M. N., Amrane, A., Karimaian, K. A., Zarrabi, M., \& Ghaffari, H. R. (2014). Potential of waste pumice and surface modified pumice for hexavalent chromium removal: Characterization, equilibrium, thermodynamic and kinetic study. Journal of the Taiwan Institute of Chemical Engineers, 45(2), 635-647. https://doi.org/10.1016/j.jtice.2013.07.0 05

Sepehr, M. N., Zarrabi, M., Kazemian, H.,
Amrane, A., Yaghmaian, K., \& Ghaffari, H. R. (2013). Removal of hardness agents, calcium and magnesium, by natural and alkaline modified pumice stones in single and binary systems. Applied Surface Science, 274, 295-305. https://doi.org/10.1016/j.apsusc.2013.0 3.042

Shukla, E. A., Matsue, N., Henmi, T., \& Johan, E. (2011). Arsenate adsorption mechanism on nano-ball allophane by Langmuir adsorption equation. Environmental Research, Engineering, and Management, 4(58), 5-9. https://doi.org/10.5755./j01.erem.58.4.3 95

Silva-yumi, J., Escudey, M., Gacitua, M., \& Pizarro, C. (2018). Kinetics, adsorption, and desorption of $\mathrm{Cd}(\mathrm{II})$ and $\mathrm{Cu}(\mathrm{II})$ on natural allophane: Effect of iron oxide coating. Geoderma, 319(2018), 70-79. https://doi.org/10.1016/j.geoderma.201 7.12.038

Speight, J. G. (Ed.). (2005). Lange's Handbook of Chemistry (16th ed.). McGraw-Hill.

Sposito, G. (2008). The Chemistry of Soils (2nd ed.). New York: Oxford University Press.

Tan, K. H. (2011). Principle of Soil Chemistry (4th ed.). Boca Raton: CRC Press Taylor \& Francis Group.

Tjahjono, A., \& Suwarno, D. (2018). The spatial distribution of heavy metal lead and cadmium pollution and coliform abundance of waters and surface sediment in Demak. Journal of Ecological Engineering, 19(4), 43-54. https://doi.org/10.12911/22998993/897 15

UNEP. (2018). Update on the Global Status of Legal Limits on Lead in Paint.

Wang, S., Du, P., Yuan, P., Zhong, X., Liu, Y., Liu, D., \& Deng, L. (2018). Changes in the structure and porosity of hollow spherical allophane under alkaline conditions. Applied Clay Science, 166, 242-249.

https://doi.org/10.1016/j.clay.2018.09.0 28

Wheller, G., Varne, R., Foden, J., \& Abbott, M. (1987). Geochemistry of quarternary volcanism in the Sunda-Banda Arc, 
Hasanah et al. / SAINS TANAH - Journal of Soil Science and Agroclimatology, 16(2), 2019, 215

Indonesia, and three-component genesis of island-arc basaltic magmas. Journal of Volcanology and Geothermal Research, 32(1-3), 137-160. https://doi.org/10.1016/03770273(87)90041-2

Whitford, D. J., Nicholls, I. A., \& Taylor, S. R. (1979). Contributions to mineralogy and petrology spatial variations in the geochemistry of quaternary lavas across the Sunda Arc in Java and Bali.
Contribution Mineralogy Petrology, 70(3), 341-356. https://doi.org/10.1007/BF00375361

Zhang, Y., Zhu, C., Liu, F., Yuan, Y., Wu, H., \& Li, A. (2019). Effects of ionic strength on removal of toxic pollutants from aqueous media with multifarious adsorbents: A review. Science of the Total Environment, 646, 265-279. https://doi.org/10.1016/j.scitotenv.2018 .07.279 